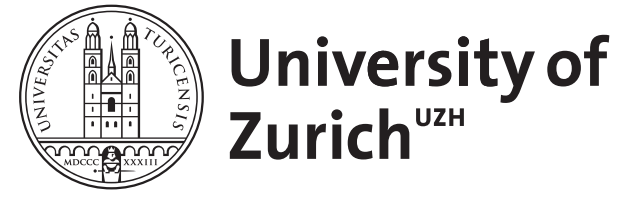
Archive

University of Zurich

University Library

Strickhofstrasse 39

CH-8057 Zurich

www.zora.uzh.ch

Year: 1956

Christ, Bible and Church in Karl Barth

Osborn, Robert T

DOI: https://doi.org/10.1093/jaarel/xxiv.2.97

Posted at the Zurich Open Repository and Archive, University of Zurich

ZORA URL: https://doi.org/10.5167/uzh-154404

Journal Article

Published Version

Originally published at:

Osborn, Robert T (1956). Christ, Bible and Church in Karl Barth. Journal of the American Academy of Religion, XXIV(2):97-102.

DOI: https://doi.org/10.1093/jaarel/xxiv.2.97 


\title{
Christ, Bible and Church in Karl Barth
}

\author{
ROBERT T. OSBORN*
}

$\mathrm{T}$ HIS year Karl Barth celebrates his seventieth birthday, and the 39th anniversary of the publication of his famous Epistle to the Romans. During the intervening years he has been cultivating the seed sown in that eventful 1917, a seed which, with the publication of the first part of the Kirchliche Dogmatik, has begun to blossom into a full-fledged Protestant "Summa." To date Barth has published ten parts (ca. 69000 pages) of an intended fifteen or sixteen part series. This is indeed an imposing beginning, which is supplemented further by a large number of monographs, pamphlets, and articles. Since Barth has done so much writing and since his views are generally regarded as basic to an understanding of contemporary theology, one is led to expect that Barth's mature thought-at least in its essentials-would be well understood by all responsible circles of Protestant theology. But, even though he has published in English translation excellent introductions to the theological views being developed in the Dogmatik, (e.g., Dogmatics in Outline, Credo, Knowledge of God and the Service of God, The Holy Ghost and the Christian Life), Barth continues to remain an enigma to most Americans. True, he is remembered for the thirty year old views expressed in the Epistle to the Romans, for his dialectical theology, his totaliter aliter, and his doctrine of the qualitative difference between time and eternity. It will even be granted gen-

* ROBERT T. OSBORN is instructor in the Department of Religion at Duke University. He received his Ph.D. at Drew Theological Seminary in June 1955. His B.D. was granted by Garrett Biblical Institute in 1950 . He has done graduate study at Princeton Theological Seminary and the University of Zürich. For one year he was a teaching assistant at Drew Theological Seminary in the field of theology. erally that he is the impetus for certain of the trends in contemporary Protestant theology, but that he has changed or developed, and what this means, would surprise many. In the popular American theological mind as I perceive it, he seems some time ago to have served his purpose. Dr. Stanley Hopper expressed this attitude when he wrote: "It appears that Barth's appeal was courageous and prophetic, but. ..."1 Whatever the reason be, his theology is regarded not merely as an enigma, but actually as a conundrum. $\mathrm{He}$ is the villain and the straw man, who, as he is caricatured, can be eliminated readily from serious consideration. For example, it is written that 'Karl Barth's devaluation of man to 'wholly other' and to absolute insignificance helped the German people to accept Hitler."2 We are interested to learn that "theistic existentialists such as Tillich, Barth, and the Niebuhr brothers... repudiate the possibility of any intellectual guidance concerning the ultimate issues." Others say that Barth agrees with Bultmann that "the earthly life of Jesus is unimportant for Christian faith." And, coming closer to the concern of this paper, we often hear, on the one hand, that Barth is just another fundamentalist, or, on the other hand, that he simply reads into the Scriptures his own philosophy and theology. Most frequently these charges are made without reference to Barth's works, as if the judgments were a matter of common knowledge and consent. Where references are made, they tend to be limited to the Epistle to the Romans or to the translated portions of the Dogmatik, implying that Barth has spent the remaining years spinning out the same old themes on his theological yo-yo. Probably some of the judgments cited are sound, even though they 
be perhaps 15-35 years old. No, Barth is indeed not deceived when he asks regarding his reception in English translation: "Am I deceived when I have the impression that there (in translation) I exist in the phantasy of far too many-even of the best men,mainly, only in the form of certain, for the most part, hoary summations of certain pictures hastily dashed off by some person at some time for the sake of convenience, just as hastily accepted, and then copied endlessly and which, of course, can easily be dismissed?" 4 Of course this picture of Barth's reception by American theology is actually a caricature; it is only fair to say that there are many excellent, just treatments of Barth's theology by British and American scholars. Nevertheless, this caricature does suggest the general situation, namely, that Barth is more of ten talked about and maligned than read and understood.

When thinking about the Word of God one often has in mind the Scriptures as such; but for Barth, as for Protestantism generally, it is something of which the Bible speaks that makes it the Word of Godnamely, the eternal Word witnessed to in the Prologue of John's Gospel. To understand what Barth means by the Word of God we must begin with his exegesis of this passage of Scripture. ${ }^{5}$

Barth interprets verse 1 traditionally, to show that the Logos is one with God in the unity of the Holy Spirit. That which exists in the beginning with God, before any thing created existed, must be God; otherwise it would be created and not be "in the beginning."

His exegesis of the second verse takes a less conventional turn. This verse commences with oviros $\eta^{\prime} v$, "this one was" or "He was" in the beginning with God. Barth would put the emphasis on the word "oviros," indicating that a very special one was in the beginning. We should read: $\mathrm{He}$ or this one was "in the beginning." John is not repeating here verse 1 , as some suggest; rather he is directing the reader to look ahead to where "He" or "this one" is identified. The reader should not be surprised, therefore, to find the same "oviros $i v$ " appearing again in the Prologue, where the Baptist says, pointing to Jesus, "ovitos iेv"- "This one was he of whom I said: He was before me." In other words, the Word in the beginning is Jesus; there is no basis here or elsewhere in the Bible for abstracting the eternal Son or Logos of God from Jesus. Barth states this idea vigorously when he says that it is just as appropriate to say that the Word is divine because it is Jesus, as to say that Jesus is divine because $\mathrm{He}$ is the Word. Barth finds this same idea supported elsewhere in the New Testament. Paul, in Colossians $1: 17$, speaking of Jesus says, "He existed before all things." Hebrews $1: 3$ says that Jesus is the one who upholds the universe by his power.

With this emphasis, Barth is essaying to understand fully the implications of Christian faith that salvation in Jesus Christ has eternal roots. God elects Jesus from the beginning (Barth's doctrine of election); Jesus Christ is not an after thought, a mere reaction to $\sin$. He is the substance of God's eternal decree. ${ }^{6}$ God exists in Jesus before the Creation. Accordingly Barth speaks of a "pre-existing God-man."7 He says that Jesus Christ is "the electing God," and that he is the "eternal will" of God.8 Brunner, for one, is bothered by such language, ${ }^{\circ}$ but Barth must be understood for what he is endeavoring to saynamely, that the eternal God is incarnate in Jesus so that God's eternity itself is incarnate. Under no circumstances are we allowed to look behind, beyond, or outside Christ for God, for God's eternal will or for His existence as Creator, Redeemer, and Reconciler. In all these forms of $\mathrm{His}$ will and activity, He is God in Jesus Christ. Barth's ideas are more acceptably stated perhaps when he refers to Jesus as the 
eternal purpose, intention, or goal of God's activity. As such $\mathrm{He}$ is "in the beginning." However, to avoid the idea that God in Himself might be other than as revealed in Jesus, or that he might be only partially committed to Jesus, Barth is inclined to extreme ideas such as: "the pre-existing God-man," or Jesus Christ as "the electing God."

The immediate implication of this thinking is that it places a specific history at the center of faith. Jesus Christ and the history which centers in Him have what Barth calls ontological significance. ${ }^{10}$ This one history is determinative of all history-it is both the ground and the goal of history in general. Therefore, for Barth, only one moment in history is of ultimate significance - the moment in which God realizes His eternal purpose to gather all things up in Jesus. Inasmuch as all things stand under the reign of sin, death, and the devil, this event also means not only the fulfillment of God's eternal will, but also the triumph of God over sin. But here, in this one event, all of this is accomplished. Here God determines the issue of "to be or not to be" for all men and the entire creation. This is the work of God-a fact prior to and, in a true sense, without the faith of man. It is the presupposition and the possibility of faith. The essence of Christianity precedes its existence.

Accordingly, the history of my faith as such is not saving history. The history of the Church in itself is not the history of salvation. Jesus Christ alone is saving history, and only in relation to Jesus can the story of my life or the story of the Church have any real meaning. The Church and the individual believer are glorified as they witness to and reflect the glory of God in Christ-the glory of Him who can accomplish and who has accomplished the salvation of men. The faith of the existing individual is not the fulfillment of or the repetition of the event of Salvation (a
Protestant version of the Roman mass). ${ }^{11}$ One could justly wonder why Barth pays any attention to faith at all. Is not salvation an accomplished fact, an actuality with eternal foundation? If Barth were logical, should he not end the discussion here with his exposition of the accomplished act of salvation? Perhaps he could add one more chapter, speculating about the eschaton and the way in which God's universal salvation shall be finally declared. These are reasonable questions. The difficulty is that Barth is not "reasonable" in this fashion. He contends that theology is not governed by principles and logic, but by the Word of God. Theology is like the perimeter of a wheel, every point of which is governed by its relationship to the hub and not primarily by its relationship to the other points on the perimeter. ${ }^{12}$ For example, Barth is convinced, on the one hand, that the Bible speaks of an accomplished salvation-of a full, effective, substitutionary atonement. But, on the other hand, this fact, this great salvation, is the Word of God; it speaks to man and confronts him with an urgent summons to faith. The Bible is essential to faith because it mediates this Word and summons; it, too, is properly called the Word of God. ${ }^{13}$ The Bible does not mediate a set of conditions which are realized in faith. The Bible does not witness to a Jesus of history who by the faith of the Apostles has become and by the renewed faith of the Church remains the Christ. The Bible does not relate an illustration of which faith provides the meaning. The Bible is not a book of mythology; it is a history book. The ChristSaviour and Redeemer-of which it speaks is $\mathrm{He}$ who is all of these things only because and as $\mathrm{He}$ was Jesus of Nazareth who lived, died, and rose on the third day.

The Bible is essential to faith in this man just as a history book is essential to an appreciation of a man who lived and died once upon a time. True, the Bible does 
contain a story of faith, but this story is better understood as the history of the faith which Jesus creates. It is not the story of how faith creates the Christ and so fulfills God's redemptive will. There can also be no faith today (as there was none then) without the Jesus of history ; and it is the good news of the Christian Gospel that Jesus of Nazareth still lives and makes such faith a possibility.

The Bible does not witness to a dead past; it witnesses to a past that is present and alive. The Jesus who was is the same Jesus who is; and the Bible, by the will of God, is an ordained means for the mediation of the past event to our present. Once upon a time Barth argued that because existence is sinful, it is incomprehensible that any aspect of man's existence, such as the Bible, should mediate divine truth. ${ }^{14}$ However, as a result of his developed Christology, and his identification of the eternal Word with Jesus-as a result of his supralapsarian emphasis upon Christ as the ground of all that is-it is not at all surprising that the words of men should be able to mediate the presence of the Eternal Word of God. Barth does not even object to the use of the term analogy. ${ }^{16}$ Scriptures especially are called to be an analogy of the eternal Word-Scriptures as well as all human words in a less concrete sense. The mystery, the "ontological impossibility," is not that the words of men should be of service to the true God, but that they should serve any other god. Sin and not grace is the insoluble problem. ${ }^{16}$

Yet, we must exercise caution. Nothing in man's words as such make them useful; they are analogous only through faith inspired by the Holy Spirit. The Christ in whose image and for whose sake everything is created, and in whose strength everything is sustained, lives. It is only as the words of men are constantly related to $\mathrm{Him}$ in and through an abiding faith that they are able to speak of God. The analogy of Scripture is the analogy of faith. The Bible, because it speaks of the Jesus of history, is chosen to be the witness to the Word of God, but only in faith is this a reality. Yet paradoxically, it is the Word of God in Christ witnessed to by Scripture and present through the Holy Spirit which creates this faith wherein the words of men speak truly of Him.

So far we have seen a two-fold use of the term "Word." Above all, the Word of God is Jesus Christ as the content of God's eternal will, as the eternal presence and existence form of God. Secondly and secondarily, it is the Bible, which points to the primary Word. And now we turn to a third form of the Word-the word which the Church proclaims. The Church is God's chosen community. This community, established upon the apostolic, scriptural witness, is integrally related to Jesus. It is the larger circle of witnesses. Jesus is like a stone dropped on the water, the apostles and the record of their witness are the "splash," and the Church is the expanding wave. Christ, the apostolic witness of the Bible, and the Church, these three are the Word of God, although Christ is the Word, the center. Jesus is historical, and every historical event has its historical precedents and consequences-Christ has the prophets and the apostles. Every event, together with its immediate environment, has a larger circumference of influence. Christ has Israel and the Church, promise and fulfillment. There is no Church where there is no Scripture or Christ. There is no Bible where there is no Christ or Church. There is no Christ without the Bible and His Church. There is no individual believer who does not encounter God in this three-fold Word. ${ }^{17}$

What then of Barth's hermeneutics? Jesus is the eternal Word of God. With this faith Barth begins. Therefore, as exegete, he is being disobedient to the faith, i.e., he is indeed faithless, if he reads the Bible for 
anything else than for its witness to Jesusthe Old Testament, as a promise of the Jesus who is to come and who yet exists already as the eternal ground of what is, and the New Testament, as the witness to Jesus who has come and who is yet to come as the fulfillment of all that is. One can expect nothing else from the Bible because Jesus Christ is the inner meaning of history as well as its fulfillment.

Yet, while it is thus inconceivable, indeed impossible, that the Bible should point to anyone but Christ, it is a fact that it often fails to point to Christ. In the case of Bultmann, the Bible seems to witness to faith itself. In the case of the liberal, it tends to reveal the rational, moral, or religious man-the religious genius. What has happened? Faith, the presupposition of the efficacy of the Bible, is lacking. The Bible is severed from God. In the hands of the sinner it points to man himself instead of to Christ; it becomes a confirmation of man's essential deity and so is transformed into the instrument of idolatry. Such misuse of the Scripture is an instance of divorce, of man's separating what God has joined together. Certainly the abuse of the Bible by separating it from Christ, the eternal Word of God, is one of the surest testimonies to the sin of man.

But, in spite of $\sin$, the Bible remains God's chosen vehicle. It is still the Word of God. It speaks of Him who has overcome sin, and who is free, in spite of the remaining vestiges of $\sin$, to make his witnesses effective. All readers of the Bible are sinners, yet justified sinners-simul peccator et justus. Every man tends to read the Bible to glorify himself (to the extent that he is a sinner). Yet God, in spite of this, uses the Bible to His glory. The Bible is free and in faith its freedom is revealed. Indeed, the very existence of faith testifies to the freedom of the Word of God.

Barth's own theological history is evidence to the freedom of the Bible. What, after all, was wrong with Barth's Romans, other than that it was an attempt to take the Bible seriously and yet fetter it with a variety of philosophical chains? As long as Barth continued to deal earnestly with the Bible and push to its center, the more he was unable to constrain its message. The disturbance, the violence which one senses in the Commentary, is nothing other than this free Word of God breaking through. It is indeed disturbing to seek to bring God and man together when your philosophical system says that they cannot be together. But the Bible was successful; its message was victorious. God and man were seen as together once and for all in Christ; Barth's totaliter aliter and other philosophical ideas faded away. It was no longer his problem to discover how grace could be possible when man and God are so unalterably opposed. It is now a problem (a theoretical problem) to ground the fact that God and man can be apart when they are so decisively united. Sin and not salvation is the mystery.

Implicit in this understanding of the centrality of Christ is the realization that no one text or concept is to be separated from its Christological center. Calvin read biblical texts dealing with predestination or election without letting the light of Christ shine upon them. Consequently he conceived of some absolute, abstract deity acting arbitrarily in his freedom-not the God in Christ. True, God is free, Barth says, but he asks "What God is free?" He who is tutored by faith in Christ knows that it is God in Christ who is free. God the Savior is free, God the Redeemer. If one must talk about the outcome of history, let him think in terms of universalism rather than in terms of the limitations upon love and grace as implied in Calvin's doctrine.

Not only is every word to be read in the light of Jesus, but every word is to be so read. Every word of Scripture can speak 
because it is the Word of God, because God in Christ is free to use this his witness. Man has no freedom to cut and alter the word, as if to prescribe for Christ the limits of his freedom. Man need not defend the Bible; indeed man can neither defend it not destroy it. The Bible has withstood the chains of both fundamentalistic and scientific or critical literalism. God is not bound by the uncritical or critical word; rather the Bible is bound to Him and in this confidence the Bible may still be read as the surest sacrament of the free grace of God-as the Word of God itself.

\section{REFERENCES}

' Stanley R. Hopper, The Crisis of Faith, Abingdon Cokesbury, New York, 1944, p. 130.

' Conrad H. Moehlman, "The Joy of a Good Conscience," The Protestant Credo, ed. Virgilius Ferm, Philosophical Library, New York, 1953, p. 32.
"Henry Nelson Wieman, "The Promise of Protestantism," The Protestant Credo, p. 188.

4Otto Weber, Karl Barth's Church Dogmatics, The Westminster Press, Philadelphia, 1953, p. 7 (From the foreword by Barth to the English edition).

- Karl Barth, Kirchliche Dogmatik, Volume II, part 2, Evangelischer Verlag, Zollikon-Zuerich, 1948, pp. 102-106. (Henceforth the Dogmatik will be referred to as K.D. 1, 1, or K.D. I, 2, etc.)

- Ibid., p. 107.

IIbid., p. 108.

K.D. II, 2, p. 157.

-E. Brunner, The Doctrine of God, The Westminster Press, Philadelphia, 1950, p. 347.

${ }^{10}$ K.D. III, 2, p. 158 f.

${ }^{11}$ K.D. IV, 1, p. 858.

12 K.D. I, 2, p. $970 \mathrm{ff}$.

13 Ibid., pp. 505-597.

${ }^{14}$ E.g., Epistle to the Romans.

${ }^{16} \mathrm{Cf}$. Hans Urs von Balthasar, Karl Barth, Hegner-Buecherei im Summa Verlag zu Olten, 1951; pp. 124-181.

${ }^{10}$ K.D. IlI, 2, p. 162 ff. Also K.D. IV, 1, p. 396"ff.

${ }^{17}$ K.D. I, 1, pp. 89-128. 